\title{
DURKHEIM E AS FORMAS ELEMENTARES \\ DA VIDA RELIGIOSA
}

Raquel Weiss ${ }^{1}$

Resumo: $O$ presente artigo apresenta alguns dos principais aspectos que estruturam a concepção de religião presente na obra de Émile Durkheim, tendo como eixo central o livro As Formas Elementares da Vida Religiosa. Para tanto, foram mobilizados três tipos principais de argumentos, que perpassam os diversos momentos do texto. O primeiro é de ordem histórico-cronológica, na medida em que apresenta as transformações na concepção de religião que culminaram com a publicação do referido livro. O segundo argumento discute de que modo suas premissas metodológicas delinearam o modo como o autor tratou do fenômeno religioso. Finalmente, o terceiro argumento articula o tema da religião com outros elementos cruciais da teoria social durkheimiana. Tomados em conjunto, esses argumentos procuram defender a importância da leitura de As Formas Elementares, ainda nos dias de hoje, na medida em que esta obra nos mostra porque a religião continua a ser um elemento tão central na vida contemporânea.

Palavras-chave: Émile Durkheim; Sociologia da Religião; As Formas Elementares da Vida Religiosa; Secularismo.

Abstract: This paper aims to present some of the main aspects structuring the conception of religious present in the work of Émile Durkheim, taking as its axis the book The Elemental Forms of Religious Life. In order to do so I followed three main arguments, spanning the different moment of the text. The first one is historical-chronological, as it presents the transformations on the conception of religion that reached its pinnacle in the referred book. The second one discusses how his methodological premises delineated the way the author dealt with the religious phenomenon. Finally, the third one articulates the theme of religion with some

${ }^{1}$ Professora adjunta do departamento de Sociologia da UFRGS, pesquisadora do NER e diretora do Centro Brasileiro de Estudos Durkheimianos. Contato: weiss.raquel@gmail.com 
other crucial aspects of durkheimian social theory. Altogether, those arguments try to make the case for the relevance of reading The Elementary Forms nowadays, as it shows us why religion is still such a central element in contemporary life.

Keywords: Émile Durkheim; Sociology of Religion; The Elemental Forms of Religious Life; Secularism.

\section{O PROBLEMA DA RELIGIÃO NA OBRA DE DURKHEIM}

A primeira forma de registro mais sistemático da preocupação de Durkheim em abordar sociologicamente os fenômenos religiosos data do ano de 1894, quando ministrou seu primeiro curso sobre este assunto, cujo conteúdo foi parcialmente publicado em L’Année Sociologique, em um artigo intitulado De la Définition des Phénomènes Religieuses (1899a). Segundo o próprio autor, foi apenas neste momento de sua carreira que se tornou mais claro em que poderia consistir uma abordagem essencialmente sociológica do fenômeno religioso.

Nessa ocasião, Durkheim tomou contato com os trabalhos de Robertson Smith e de outros autores de sua escola, em que a religião já era considerada um fenômeno social, que teria como função manter a unidade do grupo e garantir as ideias fundamentais que, no caso das religiōes primitivas, eram essenciais, para garantir a sacralidade dos clãs, então considerados compostos de homens, animais e deuses, unidos por laços de sangue (Lukes, 1984, p. 237). Quanto a essa influência, Lukes (1984, p. 238) observou que "[...] a obra de Robertson Smith e sua escola ofereceram a Durkheim uma perspectiva geral sobre a religião, que ele transformou de acordo com suas próprias preocupaçōes teóricas".

Retrocedendo aos primórdios de sua carreira (Durkheim, 1884; 1886a, $1887 b$ ) encontramos no pensamento de Durkheim uma visão significativamente mais restrita de religião, em que esta era concebida apenas enquanto uma instituição social que existia com a função de assegurar o equilíbrio da sociedade, agindo como uma forma de disciplina social. Nesse momento, a questão da religião ainda aparece de maneira apenas tangencial, no contexto 
mais geral de discussóes sobre a sociedade e seu papel é definido como produto do sentimento que vincula o indivíduo ao ser social. Enfim, antes de 1895, não se encontra nenhuma formulação mais sistemática a respeito da religião, pelos motivos expostos anteriormente.

Mas, mesmo no artigo de 1899, considerado um texto "pré-etnográfico", Durkheim apresenta uma definição essencialmente formal de religião, sustentada por uma série de hipóteses acerca da natureza deste fenômeno, de seu papel na sociedade e definindo um conjunto de questôes que deveriam ser investigadas pela Sociologia da religião. De modo geral, a tarefa do sociólogo com relação à religião deveria ser a de examinar as forças sociais que dominam o crente, concebidas enquanto um produto direto dos sentimentos coletivos.

Essa primeira guinada teve como principal consequência o deslocamento do fenômeno religioso para o centro da vida social. Mas não só. O que vemos é que a religião passa a ser considerada o lugar privilegiado para se apreender a origem da moral e das categorias do pensamento, até mesmo do pensamento científico. É por isso que o livro que representa o ápice desse processo, As Formas Elementares da Vida Religiosa, é seu tratado mais importante de sociologia da religião, mas é, ao mesmo tempo, algo que transcende essa área específica da sociologia. Trata-se, ao mesmo tempo, de um livro de sociologia do conhecimento (Schmaus, 2004; Schmaus, 1994; Jones, 2006), de epistemologia (Rawls, 2004), de sociologia da moral (Weiss, 2012; Miller, 1998) e mesmo do que poderíamos chamar de uma "sociologia geral” (Miller, 1996), na medida em que o autor procura dissecar o que há de mais elementar na vida social, na sociedade propriamente dita.

Em relação ao tema central do presente artigo, a concepção de religião, o que é importante destacar é que no livro cujo centenário celebra-se neste ano, o autor apresentou uma definição de religião diferente daquela de 1899, como veremos adiante. Por ora, o que é importante destacar é que ele consiste em uma exposição detalhada dos estudos sobre a religião realizados ao longo de vários anos e que representa a utilização de seu método sociológico para interpretar dados etnográficos. Antes de sua publicação, é verdade, já encontramos registros desta nova perspectiva. No ano letivo de 1906-1907, por exemplo, Durkheim ministrou um curso sobre as origens 
da religião, cujo conteúdo reaparece em As Formas Elementares. No ano de 1909, o autor publicou artigos que correspondem a alguns capítulos apresentados no livro de 1912 (Durkheim, 1909 a (1); 1909b; 1909c). Portanto, em As Formas Elementares da Vida Religiosa, encontramos uma abordagem bastante amadurecida do fenômeno religioso, que é visto tanto em sua singularidade quanto na relação com a sociedade como um todo.

Vamos agora focar sobre alguns aspectos particulares do livro, tentando apreender algumas premissas que estão por trás dos argumentos apresentados, que ajudam a compreender algumas de suas características gerais. $\mathrm{O}$ primeiro desses aspectos diz respeito às convicções metodológicas assumidas pelo autor que imprimem uma característica inconfundível ao seu legado.

\section{ASPECTOS METODOLÓGICOS DA OBRA}

Os argumentos apresentados no livro ora analisado são baseados em um pressuposto metodológico essencial, qual seja, o de que todos os elementos religiosos essenciais do pensamento deveriam encontrar-se, em forma germinal, nas religiōes ditas "primitivas" 2 . Por isso o primeiro passo do autor consiste exatamente em oferecer um definição precisa daquilo que entende como religião primitiva, formulada da seguinte maneira:

Dizemos de um sistema religioso que ele é o mais primitivo que nos é dado observar, quando ele preenche as duas condições seguintes: em primeiro lugar, que se encontra em sociedades cuja organização não é ultrapassada por nenhuma outra em simplicidade; é preciso, além disso, que seja possível explicá-lo sem fazer intervir nenhum modelo tomado de uma religião anterior (Durkheim, 2003, p. V).

Portanto, uma de suas tarefas consiste em encontrar tal sistema "primitivo", e é a este propósito que o autor dedica o primeiro dos três livros que

\footnotetext{
2 Para uma análise detalhada sobre o significado de se buscar as formas "elementares" da vida religiosa, veja-se o livro de William Pickering (2009) e o artigo de William Watts Miller (2005).
}

Debates do NER, Porto Alegre, ANo I3, N. 22 P. 95-II9, JUl./DeZ. 2012 
compõem As Formas Elementares. Antes de explorar o percurso transcorrido por Durkheim nas páginas desta obra, vale a pena insistir em alguns de seus elementos mais gerais. Como mencionei anteriormente, e é destacado por diversos intérpretes do autor (Pickering, 2009; Lukes, 1984; Poggi, 1992; Alun Jones, 1992; Goldenweiser, 1992), há aqui uma notável mudança na definição de religião, se comparada com seus primeiros textos, assim como aqui está pressuposta uma concepção de sociedade diferente daquela presente na fase inicial de sua carreira.

Entretanto, a despeito dessas reformulações conceituais, que são reflexos de uma mudança na compreensão ontológica dos fenômenos, há um elemento de sua teoria que se mantém desde os seus primeiros escritos: é a sua preocupação metodológica, que se evidencia no esforço do autor em seguir as prescrições enunciadas em As Regras do Método Sociológico. Com relação a isso, dois aspectos merecem destaque. $\mathrm{O}$ primeiro deles diz respeito à necessidade de caracterizar o fenômeno estudado como eminentemente social - no caso, a religião - o que justificariam a abordagem sociológica em detrimento da abordagem psicológica, econômica etc. O segundo aspecto, não menos evidente, consiste no esforço em definir com precisão o objeto, afastando as pré-noções, sejam elas provenientes imediatamente do senso comum, sejam aquelas sustentadas no próprio mundo acadêmico, consideradas ideias precipitadas ou meramente especulativas a respeito do fenômeno em questão.

$\mathrm{Na}$ verdade, inclusive a proposição inicial, de que a compreensão do fenômeno religioso supõe apreender suas formas elementares o que, por sua vez, deve ser feito a partir da investigação das formas mais simples de manifestação religiosa, está fundamentada em uma dupla premissa metodológica. A primeira delas, de inspiração cartesiana, postula que para que se conheça verdadeiramente algo, é preciso "desmontá-lo", reduzindo-o a seus elementos fundamentais; em outros termos, é preciso analisá-lo, decompô-lo, para depois reconstruí-lo. É isso o que deveria garantir um conhecimento profundo de sua composição e de seu mecanismo de funcionamento. A segunda premissa é a que diz respeito à precedência que deve ser atribuída às coisas simples, para que depois se parta para as mais complexas, pois, acredita Durkheim, a formação mais simples facilita a investigação, na medida 
em que é constituída apenas pelos elementos realmente essenciais. Por isso, é nas religiōes mais simples que Durkheim busca encontrar os elementos fundamentais do fenômeno religioso.

Evidentemente, essa ideia de "simplicidade" é possivelmente um dos pontos mais frágeis e mais contestados dessa obra, podendo ser considerada um resquício de concepções evolucionistas que ainda faziam parte do imaginário sociológico e antropológico da época e que, por isso mesmo, soa como uma ofensa às consciências contemporâneas. Porém, para que seja possível mergulhar na lógica do pensamento de um autor, é preciso saber deixar de lado o caráter problemático dessas afirmações, que poderiam nos fazer desistir da leitura, para tentar ver o que há por detrás disso, o que realmente nos importa. Não significa, é claro, ignorar o caráter datado de certos argumentos, mas de "suspender" a crítica para que se possa acompanhar mais livremente a lógica subjacente ao pensamento do autor.

Ainda no que se refere às considerações mais gerais, cabe observar que Durkheim atribui a esta sua obra um duplo escopo. O primeiro deles é o de realizar um trabalho de sociologia da religião, investigando as origens e as funçôes do fenômeno religioso, enquanto o segundo diz respeito a suas pretensôes de abordar problemas relativos à teoria do conhecimento. Tratase do problema das representações, com relação ao qual Durkheim propõe uma abordagem sobre aquelas existentes no âmbito da filosofia. Neste artigo irei discutir somente os argumentos que dizem respeito à preocupação do autor com o fenômeno religioso propriamente dito, deixando de lado as questôes que concernem à teoria do conhecimento.

\section{EM BUSCA DE UMA DEFINIÇÃO CIENTIFICA DE RELIGIÃO}

Portanto, Durkheim propõe apreender as características essenciais do fenômeno religioso, realizando aquilo que afirma ser a tarefa da sociologia, qual seja, buscar os "[...] elementos permanentes que constituem o que há de eterno na religião [...]", que são "[...] o conteúdo objetivo da ideia que se fala de religião em geral" (Durkheim, 2003, p. X). Além da preocupação em desvendar e explicar tais elementos constitutivos, tem ainda a preocupação 
de responder a questão acerca da origem do fenômeno religioso, não de sua origem histórica, mas de sua origem causal.

Antes, porém, que possa apresentar respostas a essas indagações que norteiam sua investigação, Durkheim observa a necessidade de definir precisamente o que considera como sendo religião. Como se sabe, ele rejeita o método dedutivo, que consiste em partir de uma definição elaborada a priori, para só depois tentar enquadrar a realidade neste modelo pré-concebido ${ }^{3}$. Desta forma, propõe que

[...] deixando de lado nossa concepção em geral de religião em geral, consideremos as religiões em sua realidade concreta e procuremos destacar o que elas podem ter em comum; pois a religião só pode ser definida em função das características que se encontram em toda parte onde houver religião. (Durkheim, 2003, p. 4)

É importante notar que aqui está presente o debate de Durkheim com toda uma tradição filosófica, que procurava tratar dos fenômenos sociais, inclusive do problema religioso, de maneira inteiramente a priori. O problema desta abordagem dedutiva, segundo Durkheim, é que ela não estaria fundada na realidade das coisas, isto é, não se relacionaria diretamente com os fatos da experiência ou, quando o faz, é somente para tentar obrigar a realidade a entrar em seu modelo, o que acaba por distorcer a visão da realidade mesma. Em outros registros, quando também abordou problemas temas como a moral e a educação, o autor preocupou-se em levantar essa mesma questão discutida em As Formas Elementares da Vida Religiosa. Para estabelecer uma comparação entre o modo como propõe abordar a religião e sua proposta de uma abordagem sociológica da moral, creio que possa ser interessante trazer algumas citaçóes que elucidam essa preocupação semelhante.

No texto redigido como introdução à primeira edição de $D a$ Divisão do Trabalho Social, omitido nas edições posteriores, Durkheim procura

${ }^{3}$ Para uma discussão sobre a crítica de Durkheim ao princípio da indução, veja-se Weiss (2011). 
definir em que consiste a moral, para que posteriormente possa responder a pergunta que questiona se a divisão social do trabalho é um valor moral. Naquela ocasião, ainda no início de sua carreira, Durkheim escreveu que

[...] antes de saber qual é a forma que as resume, é preciso as ter analisado, é preciso ter descrito suas características, determinando suas funções, investigado suas causas, e somente comparando o resultado de todos os casos especiais é que poderemos obter as propriedades comuns a todas as regras morais, isto é, os caracteres constitutivos da moralidade. (Durkheim, 1992, p. 273)

Note-se que nessa formulação o termo moralidade poderia ser facilmente substituído por religião.

Entretanto, mesmo para que se possa partir para a realidade, é preciso que seja possível algum critério que permita ao investigador saber como apreender os fenômenos que são religiosos, ou seja, mesmo antes que se tenha uma definição precisa do que seja a religião, o que implica conhecer um fenômeno religioso em sua essência, torna-se necessário um modo de identificar imediatamente tal fenômeno. Para resolver este problema, o sociólogo afirma que "[...] o que é necessário e possível é indicar um certo número de sinais exteriores, facilmente perceptíveis, que permitem reconhecer os fenômenos religiosos onde quer que eles se encontrem" (Durkheim, 2003, p. 4).

Quanto a isso, há mais um trecho extraído do mesmo texto mencionado na nota anterior, que se destaca pela grande semelhança com as proposições de Durkheim sobre o modo de se conhecer sociologicamente a religião. O autor coloca a questão da seguinte maneira: "[...] mas, então, como é possível reconhecer os fatos que são objeto desta ciência, isto é, os fatos morais? - A partir de algum sinal exterior e visível, e não a partir de uma fórmula que tenta exprimir sua essência." (Durkheim, 1992, p. 273) Os anos que separam a redação desses dois textos, aproximadamente três décadas, e a correlação entre os argumentos, contribui para reforçar a ideia de que há uma notável continuidade no que se refere ao caráter metodológico na teoria de Durkheim, a despeito das transformações de natureza conceitual. 
Voltando ao livro que estamos analisando, o que se nota é que antes de apresentar sua definição de religião, acompanhada das evidências que a corroboram, Durkheim procura discutir as concepções existentes, considerada por ele como concepções imbuídas de pré-noções, para, então, afastar essas concepçóes e, por consequência as pré-noções que as sustentam.

Para o autor, é possível identificar ao menos duas vertentes distintas, que procuram definir a religião a partir de aspectos que não poderiam ser aceitos como elementares. A cada uma dessas vertentes, Durkheim dedica um tópico do primeiro capítulo do livro um, sendo a primeira concepção aquela que define a religião em função do caráter sobrenatural e misterioso, enquanto a segunda é aquela que considera a religiāo como um fenômeno fundado sobre a ideia de Deus ou de algum outro ser espiritual superior.

Entre os autores do primeiro grupo, estão Spencer e Max Müller, que compartilham a ideia de que a religião é algo de sobrenatural, ou seja, algo que diz respeito "[...] a uma ordem de coisas que ultrapassa o alcance de nosso entendimento [...]" e, por isso, para esses autores “[...] a religião seria uma espécie de especulação sobre tudo o que escapa à ciência e, de maneira mais geral, ao pensamento claro." (Durkheim, 2003, p. 5). Na interpretação durkheimiana, a ideia da religião não pode ser tomada como universal, pois não seria correto atribuí-la às religiōes mais elementares, na medida em que o conjunto de dogmas e rituais não aparecia aos crentes dessas religióes como algo propriamente misterioso, mas como algo absolutamente natural e inteligível. $\mathrm{Na}$ verdade, a própria percepção do sobrenatural ou a ideia a esse respeito inexistia nos povos primitivos, pois, para tanto, seria preciso que inicialmente houvesse a percepção do que é natural, sendo natural uma ideia moderna, implicada à concepção de que o universo é um conjunto de eventos encadeados de forma lógica e necessária.

Reville e Tylor são autores que Durkheim identifica como parte do segundo grupo, na medida em que procuram definir o fenômeno religioso em virtude do fato de serem estes marcados por uma ideia de divindades. Apoiando-se em argumentos de especialistas, como Barth e Oldenberg, o sociólogo afirma que há religiōes, inclusive grandes religiōes, como é o caso do budismo, que não foram edificadas sobre uma ideia de divindade. Além 
disso, Durkheim diz que, mesmo no âmbito das religiōes deístas, existem ritos e interdições que não estão vinculadas diretamente à ideia de Deus. Por isso, Durkheim (2003, p. 18) salienta que "[...] a religião vai além da ideia de deuses ou de espíritos, logo, não pode se definir exclusivamente a partir desta última”.

Prosseguindo sua argumentação em uma sequência lógica, Durkheim dedica os dois tópicos seguintes à formulação do que considera uma definição mais "científica" da religião e que, portanto, deve dar conta, ao mesmo tempo, da universalidade e da singularidade do fenômeno. A estratégia de investigação adotada pelo autor é, como mencionei anteriormente, cartesiana e, portanto, analítica. Por isso, ao invés de buscar conhecer imediatamente o fenômeno religioso em sua totalidade, elaborando já de início uma definição precisa, o autor prefere iniciar a investigação decompondo o fenômeno em partes "elementares". Dentre os fenômenos que constituem a religião, são identificados inicialmente as crenças e os ritos, sendo os primeiros definidos como "estados de opinião" que "[...] consistem em representações [...]", enquanto os segundos são "[...] modos de ação determinados [...]" (Durkheim, 2003, p. 19).

De forma mais detalhada, as crenças são representações de algo específico, e é justamente esse algo, ou seja, o objeto da crença, que a define enquanto crença, enquanto uma representação especial, diferentemente das demais formas de representação. De acordo com Durkheim, as representações religiosas, ou seja, as crenças, caracterizam-se por impor um certo olhar que divide a realidade entre o sagrado e o profano, enquanto oposições absolutas, ou, mais especificamente, as crenças são "[...] representações que exprimem a natureza das coisas sagradas e a relação que elas mantêm, seja entre si, seja com as coisas profanas" (Durkheim, 2004, p. 24).

Os ritos, enquanto um modo de ação religioso, são concebidos como "[...] regras que determinam como o homem deve comportar-se com as coisas sagradas" (Durkheim, 2003, p. 24). Enfim, rito e crença são fenômenos religiosos que, articulados de forma sistemática, constituem uma religião, que resulta numa unidade coerente e singular, que não é parte de nenhum outro sistema de crenças, e que, portanto, funciona de acordo com sua própria lógica. 
Com isso, Durkheim garantiu a universalidade dos aspectos elementares constitutivos da religião, ou seja, ao caracterizar a religião como um sistema integrado de crenças e mitos que estabelecem uma determinada relação entre sagrado e profano, julgou ter encontrado algo que está presente em todas as religiões. Entretanto, permanecia em aberto a questão de delimitar a especificidade do fenômeno religioso, ou seja, algo que permita identificar a religião como algo distinto dos demais fenômenos sociais.

A existência de uma articulação de crenças e ritos é certamente uma condição necessária para caracterizar qualquer forma de religião, mas não é suficiente, visto que esses elementos estão presentes também na magia. Era preciso, pois, estabelecer a diferença existente entre magia e religião.

O elemento crucial para distinguir magia de religião está relacionado ao conceito de igreja, sendo esta definida por Durkheim (2003, p. 28) como “[...] uma sociedade cujos membros estão unidos por se representarem de uma mesma maneira o mundo sagrado e por traduzirem essa representação comum em práticas comuns". De acordo com a avaliação do sociólogo, não há vida religiosa sem igreja, pois "[...] onde quer que observemos uma vida religiosa, ela tem por substrato um grupo definido.”(Durkheim, 2003, p. 29)

Com relação à magia, o mesmo não ocorre. Embora as práticas mágicas sejam suficientemente difundidas no seio de um grupo social, elas diferem substancialmente da religião pelo fato de não terem a função de promover a unidade e a identidade entre os membros de um grupo. Portanto, enquanto a religião só existe quando seus membros unidos formam uma igreja, ou seja, uma unidade moral consistente, a magia não serve de base para a formação de uma tal coletividade, o que levou Durkheim (2003, p. 29) a afirmar que "[...] não existe igreja mágica”.

Reunindo os elementos apresentados anteriormente, que garantem a universalidade da definição do fenômeno religioso, àqueles que sustentam sua especificidade, Durkheim chega, assim, à sua clássica definição de religião, notadamente mais sofisticada do que aquela apresentada pelo autor nas páginas de L'Année Sociologique, no ano de 1899, que careciam de um certo "respaldo empírico". Enfim, em As Formas Elementares (2003, p. 32), a religião é definida pelo autor nos seguintes termos: 
Uma religião é um sistema solidário de crenças e de práticas relativas a coisas sagradas, isto é, separadas, proibidas, crenças e práticas que reúnem numa mesma comunidade moral, chamada igreja, todos aqueles a que ela aderem.

Na verdade, com a última parte dessa definição, Durkheim garante uma certa relação de continuidade com a definição apresentada em 1899, em que havia ressaltado somente a dimensão de obrigatoriedade. Vejamos mais de perto essa ligação que, segundo o próprio autor afirma em sua nota de número 68 do primeiro capítulo, trata-se de uma ligação de sobreposição, de aprimoramento, na medida em que não são mutuamente exclusivas.

Na primeira definição, Durkheim apresentava a religião como uma das formas de coerção social, que tinha a função de garantir a coesão, inclusive ao desempenhar o papel de representação do mundo, das tradições, dos traços culturais, respondendo, assim, a uma necessidade social. Talvez seja possível afirmar que se trata de uma definição elaborada a partir de um ponto de vista exógeno ao próprio fenômeno religioso, ou seja, a partir do ponto de vista da sociedade, enquanto organização mais abrangente. Ainda na nota 68, reconhece ter sido essa primeira definição demasiado formal, porém, destaca que ela tem a virtude de pôr em relevo o caráter social da religião, "[...] essa obrigação [que define a religião] advém, como mostrávamos, do fato de que essas crenças pertencem a um grupo, que as impõe a seus membros" (Durkheim, 2003, p. 507).

Retornando à definição de 1912, encontramos uma ligação entre os dois momentos, pois a segunda parte dessa definição diz respeito justamente ao fato de que a religião é uma comunidade moral, colocando em evidência seu caráter social. Conforme Durkheim (2003, p. 32), o mesmo observou-se "[...] ao mostrar que a religiāo é inseparável da ideia de igreja, ele [o segundo elemento] faz pressentir que a religião deve ser uma coisa eminentemente coletiva”.

Acredito que essa pequena digressão contribui para ressaltar o caráter social da religião, o que é uma condição para que se justifique a possibilidade de uma abordagem propriamente sociológica de tal fenômeno, e que, certamente, diz respeito a uma das contribuições durkheimianas mais 
importantes para consolidar o campo da sociologia da religião. Por isso, essa exposição sobre o livro As Formas Elementares da Vida Religiosa tem como objetivo tornar evidente a preocupação do autor em seguir os métodos por ele formulados em As Regras do método Sociológico, procurando destacar a própria consideração do autor acerca do que é essa realidade subjacente ao próprio fenômeno religioso, isto é, a própria sociedade. Esse passo é importante para determinar sua visão acerca da própria religião, concebida enquanto um fenômeno que tem uma causa social, por um lado, e que desempenha funçôes sociais, por outro.

$\mathrm{Na}$ verdade, a relação entre sociedade e religião tem consequências ainda mais profundas para o desenvolvimento das ideias presentes no livro em questão, que se estendem para além da dimensão conceitual. A própria compreensão ontológica acerca do que é a sociedade traz implicações para a compreensão ontológica acerca da religião, ou seja, da religião enquanto tal, da qual a definição lógica [conceito de religião], é uma derivação. Essa relação entre compreensão ontológica de sociedade e de religião ocorre justamente porque Durkheim olha para o fenômeno religioso com a mesma lógica que percebe a sociedade, ou seja, como um todo orgânico, formado por partes que desempenham funçôes específicas e que se relacionam de forma solidária. Olhando por este prisma, a religião deixa de ser um epifenômeno da sociedade, um acessório, e passa a ser tomada a partir de si mesma, de um ponto de vista endógeno; é ela própria uma sociedade, ou, ao menos, um fenômeno que opera com a mesma lógica de uma sociedade ${ }^{4}$.

Desse modo, os argumentos que garantem a possibilidade de um estudo sociológico da sociedade são os mesmos que permitem abordar sociologicamente a religião. Com isso, pode-se dizer que o que Durkheim faz nesse livro é uma análise da religião em três esferas. Em uma delas, a religião é vista como se estivesse sob as lentes de um microscópio, podendo-se examinar sua constituição mais elementar, o que implica não apenas identificar essas

\footnotetext{
${ }^{4}$ Sociedade aqui não é usada no sentido estrito do termo que supõe a presença de um território definido, mas em um sentido amplo, enquanto agrupamento de indivíduos, reunidos espacialmente ou não, que são congregados pela partilha de valores comuns e que agem de acordo com determinadas regras de conduta pré-determinadas.
}

Debates do NER, Porto Alegre, ANO I3, N. 22 P. 95-II9, JUl./DEZ. 2012 
partes, mas saber como cada uma opera individualmente, desempenhando seu próprio papel. A análise detalhada que Durkheim faz sobre as crenças e os ritos serve muito bem a esse serviço.

Numa segunda esfera, é possível olhar para a religião como um sistema autônomo, com a intenção de explicar como as partes que a constituem se relacionam entre si, conferindo o caráter específico de cada religião. Ao tratar da definição de religião, enquanto um sistema relacionado de crenças e ritos, Durkheim dá conta dessa tarefa. Finalmente, há uma esfera de investigação que pode ser definida como um olhar "panorâmico", que enxerga a religião como parte do sistema social mais abrangente. Com isso, pode-se apreender tanto as causas mais gerais que engendram o fenômeno, bem como as funções que a religião desempenha no conjunto do sistema social.

\section{ANÁLISE DO TOTEMISMO E DE SEUS ASPECTOS ELEMENTARES}

Em sua introdução, Durkheim propôs que se poderia chegar com maior facilidade ao conhecimento dos elementos fundamentais da religião, se o olhar fosse inicialmente dirigido para as formas mais simples de religião, em que tais elementos deveriam aparecer de forma mais pura e evidente. Por isso, o passo seguinte, uma vez definido o que se deve entender por religião, consistiu justamente em determinar qual é a religião que pode ser considerada como a mais elementar.

Quanto a isso, o sociólogo estabelece uma nova ruptura com correntes interpretativas já existentes, que são o animismo, teorizado por Tylor e Spencer, e o naturalismo, que tem em Max Müller e Adalbert Kuhn seus principais expoentes. Para os teóricos do animismo, teria sido o culto aos espíritos que teria dado origem ao culto religioso, enquanto para os partidários do naturalismo, tal origem deve-se ao culto da natureza. $\mathrm{O}$ cerne da divergência de Durkheim com ambas as vertentes reside justamente na explicação que cada uma dá para a origem da identificação do sagrado, ou seja, o modo como justificam a construção do divino. 
Embora os animistas defendam que foi o culto aos espíritos que teria o sonho como ponto de partida para a dimensão do divino, enquanto os naturalistas busquem nos grandes eventos da natureza a explicação para uma primeira ideia do sagrado, Durkheim defende que ambas se parecem. Isso ocorreria porque, na opinião do autor, "[...] tanto para uns como para outros, é na natureza, seja do homem, seja do universo, que se deveria buscar o germe da grande oposição que separa o profano do sagrado e [...] em ambos os casos acaba sendo a religião um produto de uma interpretação delirante" (Durkheim, 2003, p. 81-82). Ora, como se sabe, na perspectiva durkheimiana, a religião deve estar fundada na natureza das coisas, deve corresponder a algo real, portanto, não pode admitir que sua origem seja explicada como produto de um delírio. Embora os homens não identifiquem com clareza a origem do que os faz ver nos seus objetos de culto algo sagrado, o sentimento da presença do sagrado é algo real, ou seja, se eles assim o sentem, é porque deve haver algo que objetivamente provoca tal percepção.

$\mathrm{O}$ que Durkheim propõe é justamente que se investigue ainda mais a fundo o problema da identificação do sagrado, para que se identifique a realidade objetiva que está por trás desses supostos delírios; para tanto, deve-se buscar um fenômeno religioso ainda mais elementar que o animismo e o naturalismo, do qual estes não seriam senão produtos. Para o autor, esse fenômeno mais elementar é o totemismo, princípio fundamental das religiōes totêmicas, por isso concentra seus esforços em investigar, a partir de dados etnográficos, as religiōes totêmicas de seu tempo e em particular o totemismo australiano, considerada a forma mais simples dessa configuração existente. Portanto, os livros dois e três são inteiramente dedicados ao estudo da religião totêmica, e tal estudo é divido em duas partes, a primeira delas dedicada à descrição e explicação das crenças, e a segunda, aos ritos.

No que se refere às crenças, são examinadas aquelas consideradas como "propriamente totêmicas”, ou seja, aquelas que são relacionadas com a crença fundamental, que é o totem. Quatro dos capítulos do primeiro livro são dedicados à descrição e à explicação dessas crenças, mas o autor não se limita a isso, em observá-las em sua forma e funcionamento. Para Durkheim, é preciso dar conta da questão da origem dessas crenças, ou seja, é preciso 
"[...] saber como os homens puderam ser levados a constituir tal ideia [do totem] e com que materiais a construíram" (Durkheim, 2003, p. 209).

$\mathrm{Na}$ verdade, o interesse quanto à origem das crenças totêmicas não se esgota apenas na resposta sobre a origem do totem, em particular, mas fornece uma importante explicação sobre a origem da religião em geral. No seguinte trecho, Durkheim (2003, p. 166) retoma um argumento já apresentado na introdução, que chama a atenção para a importância do estudo sobre o caso particular do totemismo:

Uma religião tão estreitamente solidária ao sistema social, que ultrapassa todas as outras em simplicidade, pode ser considerada como a mais elementar que nos é dada a conhecer. Se chegarmos, pois, a encontrar as origens das crenças que acabam de ser analisadas, teremos chances de descobrir também as causas que fizeram brotar o sentimento geral.

Com essa afirmação, Durkheim prepara o terreno para chegar a uma das mais importantes conclusões de sua sociologia da religião, que diz respeito não apenas ao totemismo, mas à religião como um todo, conforme veremos mais adiante.

Então, o que está em questão é a origem do totem, definido como uma espécie de coisa que designa um clã e que cria os laços de família entre seus membros. Visto que se trata de uma crença elementar de uma religião elementar, evidentemente, Durkheim não pode aceitar como explicação que o totem tenha se originado de uma religião anterior, como sustentam Tylor e Wilken. Seria um erro lógico. Para outros autores, o totem do clã teria se originado pela perpetuação de um totem individual ao longo de gerações, o que seria, para Durkheim, um absurdo, visto que há inúmeros exemplos de clãs em que inexistem os totens particulares.

Sua explicação parte da afirmação de que não é na coisa que designa o clã que se deve buscar a identificação de um caráter sagrado, pois não é essa coisa que desperta o sentimento do sagrado. Na verdade, Durkheim observa que é o totem enquanto símbolo que é sagrado e não a coisa mesma, ou seja, é a apropriação simbólica do animal, o animal feito totem, e não o 
animal em si mesmo. É precisamente essa constatação que leva Durkheim (2003, p. 210) a afirmar que "[...] o totem é antes de tudo um símbolo, a explicação material de alguma outra coisa". Portanto, a questão acerca da origem das crenças totêmicas demanda que se identifique em que consiste essa "outra coisa", que é o que confere verdadeiramente a "sacralidade" atribuída ao totem.

A resposta a essa questão se dá pelo encadeamento lógico de uma série de argumentos bastante complexos, supostamente calcados em evidências empíricas, e que condensam toda a teoria de Durkheim sobre o sentimento moral, sobre a sociedade enquanto entidade sui generis e, finalmente, sobre as representaçôes coletivas. Aliás, é nesse momento que a ideia de representação coletiva é retomada, sendo reelaborada e aprofundada. Trata-se de um momento um pouco complicado do texto, na medida em que, ao mesmo tempo em que amplia sua concepção a esse respeito, ele pressupóe todas as construçōes anteriores sobre o problema das representações coletivas.

A questão torna-se tanto mais complexa se levarmos em conta que é exatamente essa ideia sobre representaçóes coletivas que estabelecem a conexão entre religião e sociedade, que confere uma base lógica ao argumento de que é a sociedade que está na origem de todas as crenças, enquanto é dela que emana o sentimento do sagrado. Mas, vamos por partes. Tentarei deixar de lado as complicações inerentes a essa tese sobre as representaçóes, sobre o modo com que são criados e reproduzidos os sentimentos sociais, que passam a fazer parte da percepção dos próprios indivíduo, para enfatizar o problema da relação entre deus e sociedade, que é uma das dimensões fundamentais para explicar a origem do sentimento do sagrado. Inicialmente, essa identidade é apresentada por Durkheim (2003, p. 210) no trecho a seguir:

Se ele [o totem] é ao mesmo tempo, símbolo do deus e da sociedade, não é que o deus totêmico e a sociedade são uma coisa só? [...] Portanto, o deus do clã, o princípio totêmico, só pode ser o próprio clã, mas hipostasiado e representado às imaginações sob aparências sensíveis do vegetal ou do animal que serve de totem. 
Com isso, Durkheim responde a questão acerca da realidade que o totem simboliza e que lhe garante o status de algo sagrado. Mas permanece em aberto o problema sobre as razões pelas quais a sociedade é capaz de despertar em seus membros esse sentimento de sacralidade. Nesse momento, a concepção ontológica da sociedade surge com toda clareza, consolidando-se como um fator determinante para sua interpretação do fenômeno religioso. A sacralidade da sociedade foi tematizada por Durkheim em várias outras ocasiōes, como em seus escritos sobre a educação e sobre a moral (Durkheim, 2007; 1992; 1991). Pode-se, sem dúvida, discordar da ideia do autor sobre o que é a sociedade, sobre a relação desta com os indivíduos, mas, sem aceitar, ou ao menos considerar sua premissa acerca da transcendência da sociedade sobre seus membros, do todo sobre as partes, não se pode compreender o fundamento de sua teoria sobre a legitimidade da moral, do direito e, no caso em questão, da própria religião.

De modo geral, o autor defende que "[...] uma sociedade tem tudo o que é preciso para despertar nos espíritos, pela simples ação que exerce sobre eles, a sensação do divino; pois ela é para seus membros o que um deus é para seus fiéis [...]" e um deus é "[...] antes de tudo um ser que o homem concebe, sob certos aspectos, como superior a si mesmo, e do qual acredita depender" (Durkheim, 2003, p. 211). De forma bastante resumida, é possível dizer que, assim como a figura de deus, a sociedade desempenha um duplo papel. O primeiro deles diz respeito à sua autoridade moral, que faz com que os indivíduos respeitem suas prescrições, sem questionar a utilidade ou a adequação das mesmas. $\mathrm{O}$ indivíduo obedece porque é preciso obedecer, porque percebe que é uma força superior que lhe ordena, mesmo que não identifique a origem real dessa força.

Um segundo papel da sociedade é o de reconfortar o indivíduo, assim como um deus ao qual recorrem seus fiéis nos momentos de fraqueza. Isso acontece porque a sociedade é uma potência moral, ela reúne as forças não apenas dos indivíduos de um dado momento histórico, mas ela perpetua ideias e sentimentos que perduram séculos. Um pouco mais especificamente, é nos momentos em que o indivíduo participa de alguma atividade coletiva que ele sente essa força, sente como se algo viesse a seu encontro para 
reacender seus ânimos. Esse é um importante papel desempenhado pelos ritos, que, enquanto prática social, fazem com que os indivíduos percebam que são diferentes quando estão reunidos para celebrar valores comuns. Trata-se, enfim, do processo dinamogênico engendrado pelas situações de efervescência (Miller, 2005; Weiss, 2012; Allen, 1998; Shilling; Mellor, 1998; Ramp, 1998)

$\mathrm{Na}$ vida cotidiana, mesmo o homem mais simples das sociedades menos complexas, percebe em si as representações elaboradas pela coletividade, que determinam inclusive o modo como ele, indivíduo singular, enxerga o mundo. Este indivíduo sabe que deve agir de determinada maneira, sabe que algo o impele a isso, mas não é capaz de identificar essa força como algo de origem exterior, como algo resultante da sociedade. Por isso, a religião surge como uma tentativa de explicar a natureza e os motivos dessas forças que ele percebe, por isso "[...] é obrigado a construir peça por peça a noção dessas forças com as quais se sente em contato, e por aí já se pode entrever de que maneira foi levado a concebê-las sob formas que lhe são estranhas e a configurá-la pelo pensamento." (Durkheim, 2003, p. 214)

Retornando à questão das crenças propriamente ditas, Durkheim (2003, p. 231) conclui que "[...] elas traduzem não a maneira pela qual as coisas físicas afetam nossos sentidos, mas o modo com que a consciência coletiva age sobre as consciências individuais". Se a análise das crenças levou o autor a consideraçôes acerca da própria origem da religião, no que se refere ao ritos, ele concentra-se não tanto na questão de sua origem, que já está pressuposta na explicação da origem das crenças, mas discute a sua função, qual seja, a de garantir a conservação e a reprodução das crenças. Como conclusão geral a esse respeito, afirma que têm importante função social, na medida em que garantem a formação de indivíduos aptos a agir de acordo com as crenças de sua religião, o que garante a coesão entre o grupo religioso que, na verdade, é um grupo social.

Mas como essas afirmações sobre as religiōes totêmicas podem ser aplicadas ao fenômeno religioso em geral? Já no final de seu livro, Durkheim apresenta uma generalização das principais conclusões a que chegou a partir da análise do caso concreto do totemismo australiano, tanto no que se refere 
às características imanentes a todo e qualquer fenômeno religioso, quanto no que se refere às questôes relativas ao conhecimento, que supóe sua teoria sobre as representações coletivas.

Dentre todas as ideias defendidas acerca da religião, avalio que uma das mais relevantes seja a que está implicada no argumento segundo o qual a religião não é uma representação falsa sobre o mundo, fruto de um pensamento ingênuo ou de algum delírio, que poderia ser facilmente eliminada. Certamente, o autor colocou uma nova luz sobre a questão ao tratar da religião como um fenômeno que não apenas proporciona certa unidade moral aos indivíduos, garantido a coesão necessária à existência da sociedade, mas que é responsável por estruturar e desenvolver o próprio pensamento, o próprio entendimento humano.

Além disso, na medida em que corresponde a necessidades reais da sociedade, a religião não pode ser vista com uma ideia que pode ser simplesmente eliminada, mesmo porque ela não se reduz à esfera do pensamento, mas desempenha um importante papel na orientação da ação; é um referencial do qual os indivíduos não podem abrir mão facilmente. Certamente, o até mesmo o projeto de Durkheim $(2007 ; 2008)$ para uma educação moral laica é tributário de suas ideias sobre a importância da religião, visto que para ele laicizar o ensino não poderia consistir simplesmente em uma eliminação da religião, sem pôr nada no lugar. Ao contrário, a eficácia de um projeto laico dependeria de que se encontrasse os substitutos racionais para as importantes funções desempenhadas para a religiāo; tratava-se de superar a religião, mas sem ignorar os enormes serviços por ela prestados à história da humanidade.

\section{CONSIDERAÇÕES FINAIS}

Certamente, a teoria durkheimiana sobre a religião não pode ser eximida de críticas. Lukes (1984) mesmo fez questão de reunir essas críticas em quatro grupos distintos, quais sejam, críticas etnográficas, lógicas, metodológicas e teóricas, empreendidas por autores de diversas tradições. Porém, é do mesmo autor a observação de que "[...] apesar das muitas críticas que com 
razão se fizeram a essa obra, ela continua sendo uma das mais importantes e profundas contribuiçôes à sociologia da religião" (Lukes, 1984, p. 382)

Porém, apesar desses percalços e de suas vulnerabilidades, pelo menos desde o começo da última década, As Formas Elementares vem deixando de ser considerado apenas um trabalho de sociologia da religião stricto senso - o que punha em relevo uma etnografia repleta de erros - e começa a ser analisada como uma obra que transcende tudo isso, como uma importante teoria sobre a essência da religião, como uma obra de teoria do conhecimento, de epistemologia ou ainda como coroamento de um projeto que teve início com Da Divisão do Trabalho Social, na medida em que responderia teoricamente a perguntas e hipóteses formuladas naquela época. Com isso, essa importantíssima obra começa a recobrar seu sentido original, sendolhe restituída sua ambição como empreendimento que se insere em debates filosóficos clássicos - como aquele entre empirismo e intelectualismo - e que formula explicações teóricas sobre o significado mais essencial da religião, sob qualquer uma de suas formas.

É por isso mesmo que esse livro sobreviveu às críticas, tanto fundadas quanto infundadas, e continua a ser considerado um clássico. Talvez poucos autores tenham formulado tão bem quanto Anthony Giddens 5 o que é um clássico e qual o seu estatuto para a sociologia. A construção de seu argumento começa com duas perguntas que são absolutamente centrais. Primeiro, "O que devemos entender por 'clássicos da sociologia" e, depois, "A expressão teoria social clássica tem alguma força real ou é apenas um rótulo vago e conveniente?" 6 . Depois de algumas consideraçôes bastante pertinentes, o autor chega à seguinte formulação:

Os clássicos, eu afirmaria, são fundadores que ainda falam por nós com uma voz que é considerada relevante. Eles não são apenas relíquias antiquadas, mas podem ser lidos e relidos com proveito, como fonte de reflexão sobre problemas e questões contemporâneas. Provavelmente, há várias razões para explicar porque esse sentido dos clássicos tem uma força metodológica nas ciências

\footnotetext{
${ }^{5}$ Giddens, A. Política, Sociologia e Teoria Social. São Paulo, Unesp, 1997.

${ }^{6}$ Idem, p. 13.
} 
sociais. Uma delas é metodológica. Existe um hiato lógico entre as ciências naturais e sociais; não há, nas ciências sociais, a mesma forma de conhecimento cumulativo que pode caracterizar as ciências naturais. Em segundo lugar, há, em relação a essa questão, um engajamento reflexivo inevitável da sociologia e de outras ciências sociais com o tema - ações humanas historicamente constituídas - que elas buscam analisar e explicar ${ }^{7}$.

Embora ainda muito mais possa ser dito sobre o significado dos clássicos para as ciências sociais, essas considerações já são suficientes para justificar o constante retorno ao pensamento dos autores que gozam desse estatuto. No entanto, é preciso ressaltar, esse retorno só será realmente profícuo, ou, como na afirmação de Giddens, "lido e relido com proveito", se houver um esforço contínuo e renovado voltado, em primeiro lugar, à compreensão do sentido original do pensamento nele expresso, tentando depurar a leitura de preconceitos teóricos e equívocos interpretativos. Em segundo lugar, esse processo trará resultados ainda mais interessantes se for acompanhado de um olhar que procura encontrar aqueles elementos que ecoam com mais intensidade conforme os problemas teóricos e práticos de nossa própria época, num trabalho que pode ser chamado de "atualização da teoria".

Este é um processo que parece estar ocorrendo desde as últimas duas décadas, que indicam a existência de um interesse renovado sobre esse livro, interesse esse que transcende o caráter problemático dos dados empíricos utilizados e aponta para novos significados relacionados aos argumentos ali apresentados. Em relação ao tema que estrutura este artigo, ou seja, a concepção durkheimiana de religião, creio que o mais fundamental seja a ideia, aparentemente simples e evidente, de que a religião é um produto social em seu sentido mais estrito: trata-se de algo criado por indivíduos agindo e pensando juntos, interagindo, que estabelece as próprias condições para que isso - a vida em conjunto - possa continuar a existir. É por isso que a religião é um fenômeno duplamente social, de modo que compreender a vida coletiva, em qualquer momento histórico, pressupóe que se compreenda o fenômeno religioso em geral e as múltiplas manifestações religiosas que

${ }^{7}$ Idem, p. 15.

Debates do NER, Porto Alegre, ano I3, N. 22 P. 95-II9, JUl./Dez. 2012 
estão na base das inumeráveis formas de vida coletiva que existiram ontem, que existem hoje e que existirão no futuro, sempre que for possível dizer que sobre um território não há apenas indivíduos atomizados, isolados, mas indivíduos ligados por crenças e ritos compartilhados.

\section{REFERENNCIAS}

Allen, Nicholas J. Effervescence and the origins of human society. In. N. J. Allen; William Stuart Frederick; William Watts Miller. (Org.). London: New York: Routledge, 1998.

DURKHEIM, Émile. Cours de philosophie fait au Lycée de sens. Paris. Manuscrito. Bibliothèque de la Sorbonne, Manuscript 2351, 1884 a.

. Les Études de science sociale. Revue philosophique 22: 61-80, 1886a.

DURKHEIM, Émile; GUYAU, M. L'Irreligion de l'avenir. Revue philosophique v. 23, p. 299-311. Review. Tr. 1975a, 1887b.

. Science et religion. Bulletin de la Société française de philosophie 9, séance du 19 novembre 1908, p. 56-60. Contribution to discussion, 1909a.

Examen critique des systèmes classiques sur les origines de la pensée religieuse. Revue philosophique v. 67, p. 1-28, p. 142-162. Corresponding to chs. 2 and 3 of Book One of 1912a, 1909c.

. Sociologie religieuse et théorie de la connaissance. Revue de métaphysique et de morale v. 17, p. 733-758, 1909d. Introduction to 1912a. As incorporated in the volume, section 3 of this article - p. 754-758 - is omitted).

. L'Enseignement de la Moral en l'École Primaire. Revue Française de Sociologie. XXXIII, p. 1609-1623, 1991.

. Définition du Fait Moral. In. GARAUDY, Victor (Org.). Textes, v. 2. Paris: Les Éditions de Minuit, 1992. . As Regras do Método Sociológico. São Paulo: Martins Fontes, 1999. 
. As Formas Elementares da Vida Religiosa. São Paulo: Martins Fontes, 2003

. O Ensino da Moral na Escola Primária. Novos Estudos Cebrap, n. 78, jul. 2007.

. A Educação Moral. Petrópolis: Vozes. 2008.

GOLDENWEISER, A. Review of Les Formes Elementaires de la Vie Réligieuse. In. HAMILTON (Ed.). Emile Durkheim - Critical Assesments. New York/London: Routledge, 1992.

JONES, Robert Alun. Robertson Smith, Durkheim and Sacrifice: an Historical Context of the Elementary Forms of Religious Life. In. HAMILTON (Ed.). Émile Durkheim - Critical Assesments. New York/London: Routledge, 1992.

JONES, Susan Stedman. Action and the question of the categories: a critique of Rawls. Durkheim Studies, 2006.

LUKES, Steven. Émile Durkheim: su Vida y su Obra. Madrid: Centro de Investigaciones Sociológicas, 1984.

MILLER, William Watts. Durkheim, Kant, the immortal soul and God. In. On Durkheim`s Elementary Forms of Religious Life. ALLEN, Nicholas J.; PICKERING, William Stuart; MILLER, William Watts (Org.). London: New York: Routledge, 1998.

MILLER, W. W. Dynamogénique and Élementaire. Durkheim Studies, 11, p. 18-32, 2005.

PICKERING, W. S. F. Durkheim's Sociology of Religion - Themes and Theories. Cambridge: James Clarke \& Co, 2009.

POGGI, Gianfranco. The Place of Religion in Durkheim's Theory of Institutions. In. HAMILTON (Ed.). Emile Durkheim - Critical Assesments. New York/London, Routledge, 1992.

RAMP, William. Effervescence, differentiation and representation in The Elementary Forms. In. On Durkheim`s Elementary Forms of Religious Life, 
N. J. Allen; W. S. F Pickering; William Watts Miller. (Orgs.). London: New York: Routledge, 1998.

RAWLS, Anne Warfield. Epistemology and Practice - Dukheim's The Elementary Forms of Religious Life. Cambridge/New York: Cambridge University Press, 2004.

SCHMAUS, Warren. Durkheim's philosophy of science and the sociology of knowledge: creating an intellectual niche. Science and its conceptual foundations. Chicago: University of Chicago Press, 1994.

. Rethinking Durkheim and his tradition. Cambridge: Cambridge University Press, 2004.

SHILLING, Chris; MELLOR, Philip A. Durkheim, Morality and Modernity: Collective Effervescence, Homo Duplex and the Sources of Moral Action. The British Journal of Sociology v. 49, n. 2, p. 193-209, jun. 1998.

WATTS-MILLER, William. Durkheim, Morals and Modernity. London/ Montreal: UCL Press/McGill-Queen’s University Press, 1996.

WEISS, Raquel. From Ideas to Ideals: effervescence as the key to understanding morality. Durkheim Studies 18, 2012. 